\title{
TWO NEW BRAZILIAN SPECIES OF TACHIA (GENTIANACEAE: HELIEAE)
}

\author{
LENA STRUWE ${ }^{1,2,3}$, MATTHEW P. KINKADE 2 \& PAUL J.M. MAAS 4
}

\begin{abstract}
SUMMARY
Two new species of Tachia (Gentianaceae: Helieae) are described from Brazil. They share the unusual characteristic of quadrangular, winged stems, formerly only known from Tachia longipes in Suriname. They differ from this species in their larger, winged, keeled, and long-acuminate calyx lobes. Tachia lancisepala, spec. nov., is only known from one collection from the State of Rondônia in Brazil, and has unusually large and broadly funnelshaped corollas and ovate leaves with winged petioles. Tachia siwertii, spec. nov., has been found in three separate areas in southern Amazonas and Pará (Brazil) and is characterized by more elliptic leaves, unwinged petioles, and a narrower corolla than T. lancisepala.
\end{abstract}

\section{RESUMO}

Duas novas espécies de Tachia (Gentianaceae: Helieae) oriundas do Brasil são descritas. Ambas compartilham os ramos quadrangulares e alados, características observadas originalmente apenas em Tachia longipes do Suriname. Diferem dessa espécie em seus lobos do cálice maiores, alados e longamente acuminados. Tachia lancisepala, spec. nov., é conhecida somente de uma coleção do estado de Rondônia no Brasil e tem corolas particularmente grandes e amplamente infundibuliformes e folhas ovadas. Tachia siwertii, spec. nov., tem sido encontrada em três diferentes áreas ao sul do Amazonas e Pará (Brasil), sendo caracterizada por folhas mais elípticas, pecíolos não alados e pela corola mais estreita do que de T. lancisepala.

Key words: Gentianaceae, Helieae, Tachia, Neotropics, systematics, taxonomy, new species.

\section{INTRODUCTION}

During revisionary work in the Neotropical tribe Helieae of Gentianaceae two new species of Tachia Aubl. were identified. Plants of Tachia are easily recognized in the field as shrubs, small trees, or rarely lianas with opposite and entire leaves, no latex or stipules, 1 or 2 sessile flowers in leaf axils, and 5-merous sympetalous, and hypogynous flowers (Struwe et al., 1999). The only other woody gentian genus with axillary, sessile flowers in the New World is the poorly known Zonanthus Griseb., a monotypic

1) Department of Ecology, Evolution, and Natural Resources, Rutgers University - Cook College, 237 Foran Hall, 59 Dudley Road, New Brunswick, NJ 08901, USA.

2) Department of Plant Biology and Pathology, Rutgers University - Cook College, 59 Dudley Road, New Brunswick, NJ 08901, USA.

3) Corresponding author: struwe@aesop.rutgers.edu

4) Nationaal Herbarium Nederland, Utrecht University branch, Heidelberglaan 2, 3584 CS Utrecht, The Netherlands. 


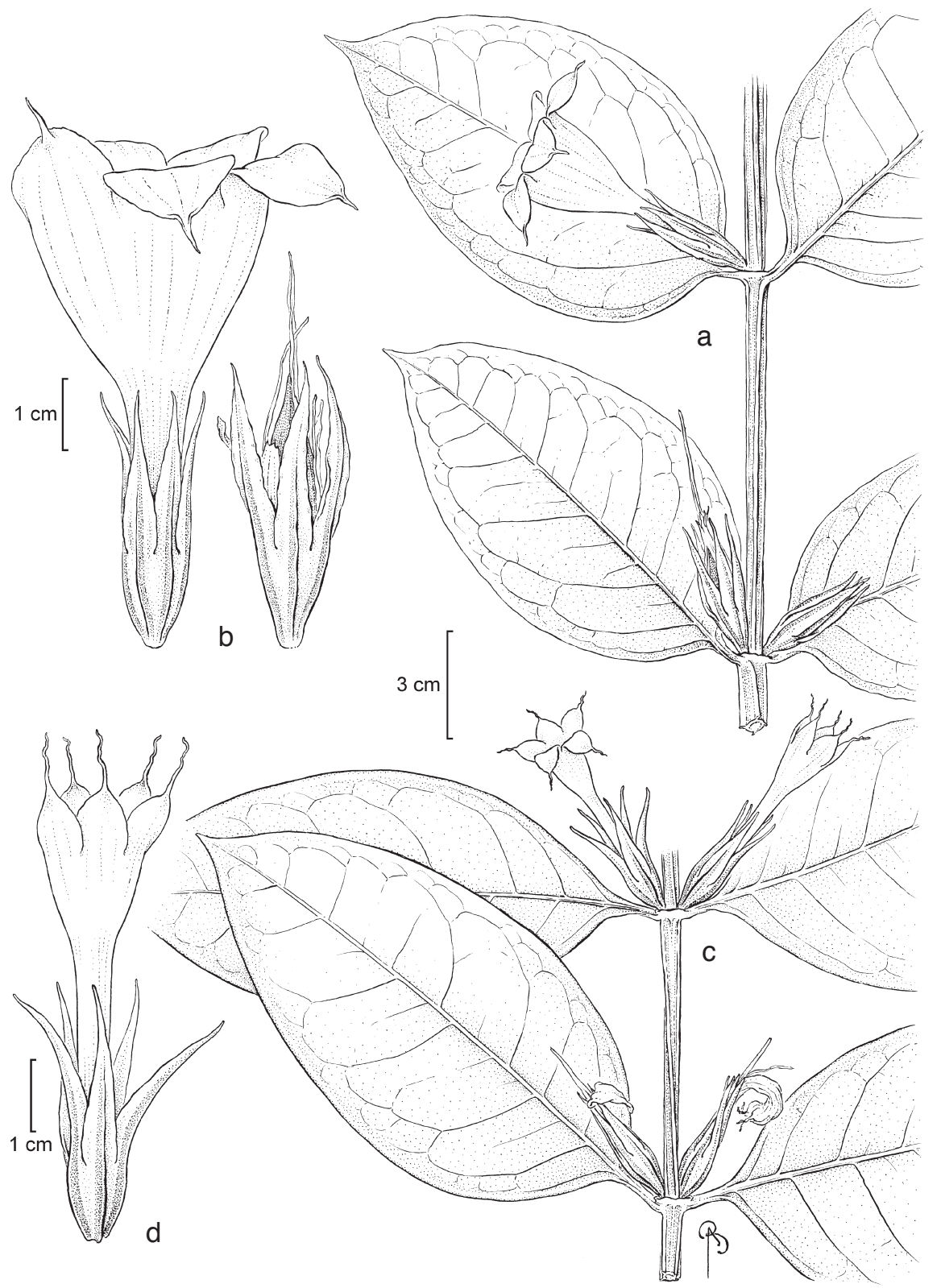

Fig. 1. - a \& b. Tachia lancisepala Struwe, Kinkade \& Maas. a. Habit; b. flower (Santos et al. 758, MG). — c \& d. Tachia siwertii Struwe, Kinkade \& Maas. c. Habit; d. flower (Egler 1246, MG).

endemic of Cuba, which might be closely related to Tachia. Macrocarpaea (Griseb.) Gilg and Chorisepalum Gleason \& Wodehouse with branched cymose inflorescences also appear to be close relatives to Tachia in molecular and morphological phylogenetic studies (Struwe et al., 2002). 
Both new species have winged, quadrangular stems, which is previously only known from Tachia longipes L. Cobb \& Maas in Suriname (Cobb \& Maas, 1998). With the addition of these two species, Tachia now includes 13 species.

\section{TAXONOMIC TREATMENT}

\section{Tachia lancisepala Struwe, Kinkade \& Maas, spec. nov. - Fig. 1a, b; Map 1}

Tachia longipedis similis, differt foliis venis secundariis utrinque 3-7 (versus 2), lamina late ovata (versus obovata) et breviore $(13-13.5 \mathrm{~cm}$ versus $17-31 \mathrm{~cm}$ ), calyce alato et longiore (36-40 versus $14-16 \mathrm{~mm}$ longo). Tachia siwertii similis, sed differt petiolis alatis, foliis venis secundariis utrinque 3-7 (versus 7-11), lamina late ovata (versus elliptica ad ovata), corolla fauce 40-45 mm diametro (versus 24-25 mm). - Typus: J.U. Santos et al. 758 (holo MG), Brazil, Rondônia, Municipio de Vilhena, Local Ponta de Pedra, Serra dos Parecis, 12 May 1984.

Shrub, up to $2 \mathrm{~m}$ high; branches woody, quadrangular, hollow, up to c. $9 \mathrm{~mm}$ thick, winged (wings c. $2 \mathrm{~mm}$ wide). Leaves ovate, $13-13.5$ by $6.8-7.6 \mathrm{~cm}, 1.8-1.9$ times longer than wide; venation pinnate with 3-7 pairs of secondary veins at an angle of $50-75^{\circ}$ towards midvein, coriaceous when dry; base attenuate; apex slightly acuminate; petiole c. $5 \mathrm{~mm}$ long, winged. Calyx $36-40 \mathrm{~mm}$ long, c. $7 \mathrm{~mm}$ wide at point of fusion of lobes, divided $2 / 3$ of its length, strongly winged and keeled; lobes narrowly ovate, 28 by $5-6 \mathrm{~mm}$; apex long-acuminate; margin membranaceous. Corolla yellow, funnelform with broadly expanded tube, c. $70 \mathrm{~mm}$ long, 2-2.3 times longer than calyx, 10-11 $\mathrm{mm}$ wide at base, $40-45 \mathrm{~mm}$ wide at mouth; lobes ovate, erect or spreading, 18 by 11-12 $\mathrm{mm}$; apex acuminate, darker than rest of lobes, with 5-7 $\mathrm{mm}$ long extension. Stamens inserted in corolla tube, not exserted from corolla mouth; filaments strongly curved at apex, c. $45 \mathrm{~mm}$ long; anthers c. $4.5 \mathrm{~mm}$ long. Style c. $40 \mathrm{~mm}$ long; stigma bilamellate, 4.5 by $2 \mathrm{~mm}, 2$ times longer than wide. Capsule narrowly ellipsoid, 31 by $8 \mathrm{~mm}$, with small style remnant, calyx persistent in fruit; seeds globose, dark brown, c. $0.7 \mathrm{~mm}$ diam.; testa surface spinose with pointed peaks at joints of testa cell walls.

Distribution - Tachia lancisepala is only known from Serra dos Parecis, near Vilhena in Rondônia (Brazil), which is near the Guapore River and the Bolivian border. Serra dos Parecis is a long and narrow northwest-southeast mountain range in an area bordering Amazonia with semi-deciduous forests (Daly \& Mitchell, 2000).

Habitat \& Ecology - Very little is known about the ecology and habitat of this very rare species. The only collection was found in (non-inundated) terra firme forest on sandy soil.

2. Tachia siwertii Struwe, Kinkade \& Maas, spec. nov. - Fig. 1c, d; Map 1

Tachia longipedis similis, differt foliis venis secundariis utrinque 7-11 (versus 2), lamina elliptica vel plusminusve ovata (versus obovata), calyce alato et $31-38 \mathrm{~mm}$ longo (versus 14-16 mm longo). Tachia lancisepalae similis, differt petiolis non alatis, foliis venis secundariis utrinque 7-11 (versus 3-7), lamina elliptica vel plusminusve ovata (versus late ovata), corolla fauce 24-25 mm diametro (versus 40-45 mm). - Typus: A. Henderson 367 (holo INPA (no. 146.735); iso BELEM n.v., NY, U), Brazil, Amazonas, Municipio de Borba, BR 230 Estrada Transamazonica, $26 \mathrm{~km}$ E of Sucunduri, ca. $6^{\circ} 50^{\prime} \mathrm{S}, 59^{\circ} 00^{\prime} \mathrm{W}$, 8 May 1985. 
Liana or small tree, up to $2 \mathrm{~m}$ high; branches woody, quadrangular, hollow, 5-7 mm thick, winged (wings $1-2 \mathrm{~mm}$ wide). Leaves elliptic, $13-21$ by $4.8-7.2 \mathrm{~cm}, 2.7-3$ times longer than wide; venation pinnate with $7-11$ pairs of secondary veins at an angle of $60-80^{\circ}$ towards midvein, coriaceous when dry; base attenuate; apex acute; petiole 2-12 mm long, not winged. Calyx 31-38 mm long, 7-9.5 mm wide, divided c. 1/2 to $2 / 3$ of its length, strongly winged, except on lobes; lobes narrowly ovate, $25-27$ by 4-5 mm; apex long-acuminate; margin membranaceous. Corolla white, narrowly funnelform, 65-95 mm long, 2-3 times longer than calyx, 6-9 mm wide at base, 24-25 $\mathrm{mm}$ wide at mouth; lobes ovate, erect, $15-17$ by $9-11 \mathrm{~mm}$; apex strongly acuminate, not darker than rest of lobes, 5-8 $\mathrm{mm}$ long extension. Stamens inserted in corolla tube, not exserted from corolla mouth; filaments curved at apex, c. $50 \mathrm{~mm}$ long; anthers c. $6 \mathrm{~mm}$ long. Style c. $40 \mathrm{~mm}$ long; no mature stigma seen. Capsule narrowly ellipsoid (as immature), 25 by $4-5 \mathrm{~mm}$, with up to $10 \mathrm{~mm}$ long style remnant, calyx persistent in fruit; seeds not seen.

Distribution - The three collections of Tachia siwertii have been found far disjunct from each other in the southern parts of the Brazilian states of Amazonas and Pará, with over $1000 \mathrm{~km}$ between the two most remote localities.

Habitat \& Ecology - Tachia siwertii is known from an area of Brazil where drier high-land cerrado meets lowland Amazonian forest (Amazonia). Pockets and extensions of the rain forest along rivers create an uneven and dissected border between the more humid Amazonia and the cerrado vegetation (Daly \& Mitchell, 2000).

Etymology - Tachia siwertii is named in honour of Siwert Nilsson (1933-2002), an internationally renowned Swedish palynologist.

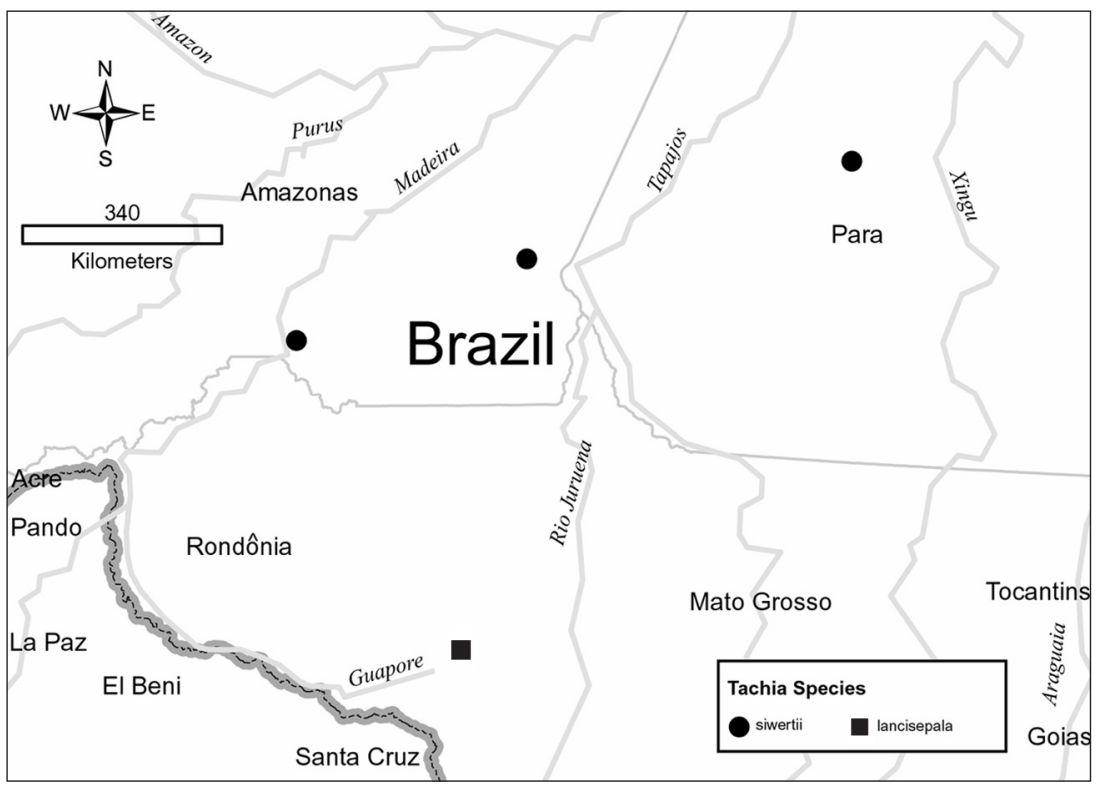

Map 1. Distribution of Tachia lancisepala Struwe, Kinkade \& Maas (•) and T. siwertii Struwe, Kinkade \& Maas (ם) in south-western Brazil. 
Additional specimens:

BRAZIL: Amazonas: Município de Humaitá, estrada Humaitá-Jacarecanga, km 64, a 3 km ao Sul, Teixera et al. 1160, 15 June 1982 (INPA (no. 104.896), NY). Pará: Alto Tapajós, Rio Cururú, Erereri, Egler 1296, 10 Feb. 1960 (MG (no. 24.343), NY).

\section{DISCUSSION}

The genus Tachia expresses a wide range of morphological diversity within a genus of only a dozen species. Most species are clearly distinct from each other and good key characters often include good field characters such as stem shape, leaf venation patterns, calyx size and the presence or absence of keels and/or wings, corolla-calyx length ratios, and corolla shape. A new trilingual field guide to all species utilizes these easy-to-use characters and will soon be available for distribution (Peters et al., in prep.). Despite these clear morphological differences among species, evolutionary relationships between species are less clear and phylogenetic data are currently being obtained to give a better estimate of the evolution of this genus (Struwe \& Kinkade, unpublished).

Tachia lancisepala and $T$. siwertii are clearly closely related and share several unique characteristics. Leaf venation patterns have been used as a cardinal character to split Tachia into two sections, Tachia sect. Tachia with pinnately veined leaves with many secondary veins, and Tachia sect. Schomburgkiana with arcuately 2- or 3-veined leaves (Maguire \& Weaver, 1975). However, T. lancisepala and T. siwertii do not naturally fit into any of these two sections. Their leaves have pinnate venation, but there is a strong arcuate element in their venation patterns, especially in T. lancisepala in which the basal secondary veins curve prominently toward the apex of the leaf. In $T$. siwertii, the basal secondary veins are extending more straight to the outer edge of the leaf (Fig. 1a, c).

Previous to the discovery of these new species, T. longipes was the only known Tachia species with angular and winged stems. This rare species from Suriname differs from T. lancisepala and $T$. siwertii in its herbaceous habit, solid stem, smaller calyx with obtuse lobes, and other vegetative and floral characteristics. The long-acuminate winged calyces of the two new species are reminiscent of $T$. schomburgkiana Benth., another Guianan species, which differs in its strongly 2-veined leaves with arcuate veins, a membranaceous calyx (vs nearly woody) and narrower corollas. The broadly expanded corolla tube of T. lancisepala is similar to the corolla of T. grandiflora Maguire \& Weaver, a central Amazonian and Guianan species, which has leaves with straight secondary veins and a small calyx with obtuse calyx lobes (see Gentian Research Network, 2005, for photos and other information of other Tachia species).

\section{KEY TO SPECIES OF TACHIA WITH WINGED STEMS}

1a. Calyx 31-40 mm long, lobes strongly winged with long, acuminate apex; leaves elliptic, 130-210 mm long; secondary veins many and only bent towards apex in

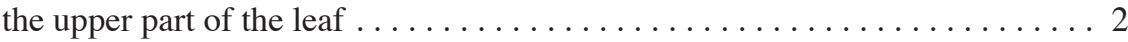

b. Calyx 14-16 mm long, lobes not winged with obtuse to acute apex; leaves obovate, $170-310 \mathrm{~mm}$ long; secondary veins few and all strongly bent towards apex.

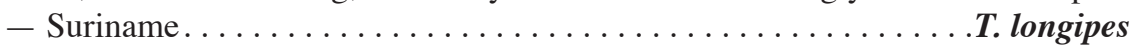


2a. Corolla c. $70 \mathrm{~mm}$ long; corolla tube broadly expanded ( $40-45 \mathrm{~mm}$ wide at mouth).

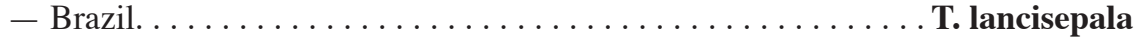

b. Corolla 65-95 mm long; corolla tube narrow (24-25 $\mathrm{mm}$ wide at mouth); corolla

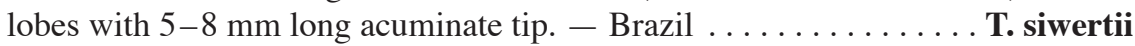

With this discovery the distribution of the genus also suddenly extends hundreds of miles southwards to the southern edge of the Amazon basin. The addition of these two new species in marginal areas of the distribution of the genus indicates that the biodiversity of Tachia is still not yet fully known. It is likely that additional specimens can be found in intermediate and neighbouring areas of similar habitats, both of these and other species. Tachia plants are quite inconspicuous when not in flower, and could easily be overlooked. Furthermore, individuals are rarely abundant within the same area, and specimens are usually found as scattered, isolated plants in the understorey in the rain forest. Both species described here are found in terra firme forest in poorly collected areas. However, it is also possible that these rare species are long-isolated, relictual populations. Few species in the Helieae show large, contingent distributions in the Amazon basin, and narrow endemics are more common. All other Tachia species are more northern (Amazon Basin, Guayana Shield) or western (Andes, Costa Rica). Phylogenetic and biogeographic studies of Tachia as well as all of Helieae are underway to investigate the historical patterns of these distributions.

\section{ACKNOWLEDGEMENTS}

We are deeply grateful to Laura Cobb who provided the initial identification of these two species. We also thank Lubbert Y.Th. Westra for help with Latin descriptions, and two reviewers for comments on a previous version of this manuscript. Maria Fernanda Calió provided the abstract in Portuguese, Wendy Peters designed the distribution map, and Bobbi Angell made the drawings. We are thankful to the following herbaria and staff, who provided access to material and invaluable help: INPA, MG, NY, and U. LS acknowledges financial support from the National Science Foundation (grant 317612 to LS) and the Rutgers Research Council. The research for this paper was partly done by Matthew Kinkade as a NSF-funded REU undergraduate student at Rutgers University.

\section{REFERENCES}

Cobb, L. \& P.J.M. Maas. 1998. A new species of Tachia (Gentianaceae) from Suriname. Brittonia 50: $11-18$.

Gentian Research Network, Tachia home page. 2005. Accessed 8 June 2005. (http://www.rci.rutgers.edu/ struwe/gentnet/genera/genTach.htm); images (http://www.rci.rutgers.edu/ struwe/gentnet/genera/genTachimg.htm).

Daly, D. \& J.D. Mitchell. 2000. Lowland vegetation in tropical South America. In: D.L. Lentz (ed.), Imperfect balance: 391-454. Columbia University Press, New York.

Maguire, B. \& R.E. Weaver. 1975. The Neotropical genus Tachia (Gentianaceae). J. Arnold Arbor. 56: $103-125$.

Struwe, L., J.W. Kadereit, J. Klackenberg, S. Nilsson, M. Thiv, K.B. von Hagen \& V.A. Albert. 2002. Systematics, character evolution, and biogeography of Gentianaceae, including a new tribal and subtribal classification. In: L. Struwe \& V.A. Albert (eds.), Gentianaceae: systematics and natural history: 21-309. Cambridge University Press, Cambridge.

Struwe, L., P. J.M. Maas, O. Pihlar \& V.A. Albert. 1999. Gentianaceae. In: P.E. Berry, K. Yatskievych \& B.K. Holst (eds.), Flora of the Venezuelan Guayana, vol. 5: 474-542. Missouri Botanical Garden, St. Louis. 